\title{
PENYULUHAN MENGENAI PENGGUNAAN PESTISIDA YANG BAIK DAN BENAR DI DESA JURUG KECAMATAN SOOKO KABUPATEN PONOROGO
}

\author{
Sisca Mayang Phuspa ${ }^{1}$, Eka Rosanti ${ }^{2}$ \\ 1 Univversitas Darussalam Gontora \\ 2 Univversitas Darussalam Gontora
}

\begin{abstract}
Abstrak
Desa Jurug Kecamatan Sookomerupakan daerah dengan85\% penduduknya bermata pencaharian sebagai petani.Pestisida merupakan salah satu unsur yang sulit dipisahkan dengan kegiatan pertanian.Berdasarkan hasil pengamatan dan kuesioner,

Pestisida, Petani, petani di Desa Jurug belum mengetahui bagaimana bahaya pestisda untuk kesehatan Berdasarkan referensi, pestisida yang terkandung dalam darah dapat menyebabkan efek toksik dalam menghambat enzim kolinesterase yang dapat mengganggu sistem saraf. Masyarakat petani Desa Sooko belum pernah mendapatkan penyuluhan dari Puskesmas terdekat tentang kesehatan kerja khususnya pada petani yang terkait dengan penggunaan pestisida. Selain itu kesadaran petani akan kesehatan juga masih rendah, terlihat dari hasil kuesioner pretest belum diperhatikannya cara menggunakan pestisida yang baik dan benar serta pemakaian APD sebagai upaya preventif terhadap terjadinya penyakit akibat kerja dari penggunaan pestisida belum maksimal. Berdasarkan hasil penyuluhan, terdapat peningkatan skor kuesioner (post-

test) sebesar 50\%. Hal ini menunjukkan peningkatan pemahaman peserta dalam pemakaian pestisida dan bahaya pestisida.Hal ini baik untuk meningkatkan kesadaran masyarakat, khususnya petani untuk menggunakan pestisida yang aman bagi kesehatan.Peningkatan kesehatan petani diharapkan menjadi awal dari peningkatan produktifitas di bidang pertanian.
\end{abstract}

\section{Pendahuluan}

Penerapan aspek Keselamatan dan Kesehatan Kerja (K3) saat ini tidak hanya berpusat pada industri formal, namun juga pada industri informal. karena layaknya industri formal tempat kerja di industri atau kegiatan informal juga memiliki elemen yang sama yaitu terdapat tenaga kerja, alat, dan lingkungan kerja yang saling berinteraksi. Jika interaksi tersebut berjalan tidak sesuai dengan standar maka dapat mengakibatkan terjadinya Penyakit Akibat Kerja (PAK).

Berdasarkan data Dinas Pekerjaan Umum (DPU) Kabupaten Ponorogo Tahun 2015 jumlah petani di Ponorogo adalah 27.755 orang atau $22,6 \%$ dari jumlah keseluruhan penduduk dengan luas lahan seluruhnya dalah 5.119.905 hektar. Petani merupakan jumlah tenaga kerja terbesar kedua setelah pedagang yaitu 28.355 orang atau $23 \%$. Sebagai sektor andalan daerah petani perlu mendapatkan perhatian dari segi kesehatan karena akan berpengaruh pada produktifitas kerja.

Salah satu desa yang menjadi perhatian tim pengusul adalah Desa Jurug Kecamatan Sooko Kabupaten Ponorogo dikarenakan sebagain besar penduduknya bermata pencaharian sebagai petani yaitu sebesar 86\% (Data BPS Kabupaten Ponorogo Tahun 2015). Desa Jurug memiliki luas wilayah 11,3 $\mathrm{Km}^{2}$, dengan jumlah penduduk 6.714 warga yang merupakan penduduk terbanyak dari 5 desa lain yang merupakan wilayah Kecamatan Sooko.

Tabel 1. Jumlah fasilitas kesehatan di Kecamatan Sooko

\begin{tabular}{|l|l|}
\hline Jenis Fasilitas Kesehatan & Unit \\
\hline Rumah Bersalin & - \\
\hline Puskesmas & 1 \\
\hline Puskesmas Pembantu & 2 \\
\hline Polindes/Poskesdes & 6 \\
\hline Posyandu & 29 \\
\hline
\end{tabular}




\begin{tabular}{|l|l|}
\hline Dokter Praktek Swasta & 2 \\
\hline Bidan Praktek Swasta & 8 \\
\hline Apotek/Toko Obat & 1 \\
\hline
\end{tabular}

Sarana kesehatan tidak akan operasionaltanpa didukung oleh tenaga medis yangmemadai. Jumlah dokter yang berdomisili diKecamatan Sooko sebanyak 2 orang dokterumum. Sementara tenaga bidan yang ada 10 orang dan tenaga kesehatan lain 16 orang.Rasio jumlah tenaga medis terhadap jumlahpenduduk yang ada pada tahun 2014mencapai 1:900, yang berarti setiap tenagamedis secara ratarata harus siap melayani900 penduduk.

Kurangnya SDM kesehatan menjadikan kurang maksimalnya pelaksanaan program kesehatan kerja di Kecamatan Sooko.Program kesehatan kerja, khususnya untuk pekerja di bidang pertanian belum pernah dilakukan di Desa Jurug.Sehingga pengetahuan petani tentang bahaya pestisida terhadap kesehatan juga terbatas. Sementara pemakaian pestisida tidak bias dilepaskan dari pekerjaan di bidang pertanian. Hal itulah yang melatarbelakangi kegiatan pengabdian kepada masyarakat yang bertema tentang Penggunaan Pestisida yang Baik dan Benar.

\section{MASALAH}

Masyarakat petani Desa Sooko belum pernah mendapatkan penyuluhan dari Puskesmas terdekat tentang kesehatan kerja khususnya pada petani yang terkait dengan penggunaan pestisida. Selain itu kesadaran petani akan kesehatan juga masih rendah, terlihat dari belum diperhatikannya cara menggunakan pestisida yang baik dan benar serta pemakaian APD sebagai upaya preventif terhadap terjadinya penyakit akibat kerja dari penggunaan pestisida belum maksimal.

Di sektor pertanian, pestisida merupakan aspek yang tidak terpisahkan dengan petani. Hal tersebut disebabkan karenapestisida digunakan oleh petani untuk mengendalikan vektor dan hama tanaman dalam memperoleh hasil pertanian yang baik. Berdasarkan referensi, pestisida yang terkandung dalam darah dapat menyebabkan efek toksik dalam menghambat enzim kolinesterase yang dapat mengganggu sistem saraf. Oleh karena itu penggunaan pestisida di sektor pertanian tidak dapat dihindari dan akan terakumulasi dalam darah petani.

Ada beberapa faktor risiko yang mempengaruhi mengakibatkan keracunan pestisida pada petani, antara lain sikap/ perilaku pengguna pestisida, penggunaan alat pelindung, serta kurangnya informasi yang berkaitan dengan risiko penggunaan pestisidayang baik dan benar (Afriyanto, 2008).

Masyarakat di Desa Jurug Kecamatan Sooko sebagian besar adalah petani.Terdapat 12 Dusun dan 12 komunitas tani di Desa Jurug Kecamatan Sooko.Berdasarkan hasil pengamatan, petani menggunakan pestisida sesuai dengan keinginan bahkan menambah dosis dengan harapan dapat maksimal membunuh hama, selain itu belum adanya APD yang dipakai oleh petani pada saat aktivitas menyemprot tanaman padi, bahkan petani sering melakukan aktivitas pencampuran pestisida dengan bahan lain. Berdasarkan keterangan tersebut maka Desa Jurug Kecamatan Sooko layak untuk di jadikan lokasi pada pengabdian ini.

\section{Pendidikan Masyarakat}

\section{METODE}

Metode ini bertujuan untuk meningkatkan pengetahuan dan pemahaman masyarakat, khususya petani di Desa Jurug mengenai bahaya pestisida dan cara menggunakan pestisida yang baik dan aman. Pengukuran tingkat pegetahuan masyarakat dievaluasi dengan pre-test dan post-test menggunakan instrumen berupa kuesioner.Analisis data menggunakan aplikasi Microsoft Excel.Kegiatan pendidikan masyarakat atau penyuluhan dilaksanakan pada bulan Oktober 2016 di Balai Desa Jurug, Kecamatan Sooko.

Pelatihan

Pelatihan dalam hal ini dilaksanakan bersamaan dengan pendidikan masyarakat / penyuluhan.Pelatihan atau workshop ini khusus memberikan simulasi penggunaan pestisida kimia yang aman.Dalam pelatihan ini peserta juga dilatih membuat pestisida yang berbahan herbal yang alami sehingga meminimalisir potensi racun berbahaya bagi kesehatan manusia.

\section{PEMBAHASAN}

Menyikapi adanya kesenjangan pengetahuan masyarakat, terutama petani, mengenai bahaya pestisida maka pendidikan masyarakat perlu dilakukan.Kegiatan ini dilaksanakan di Balai Kantor Desa Jurug serta diikuti oleh 15 orang peserta yang merupakan anggota kelompok tani.

Kegiatan pendidikan masyarakat atau penyuluhan tentang bahaya pestisida dan cara menggunakan pestisida yang baik dan benar ini diawali dengan pre-test untuk mengukur pemahaman awal peserta 
tentang materi yang akan disampaikan. Pertanyaan pada pre-test merupakan pertanyaan seputar materi tantang pestisida. Hasil pre-test menunjukkan bahwa rata-rata skor peserta penyuluhan adalah 5,5 dengan perincian pada tabel dibawah ini.

Tabel 1. Rekapitulasi nilai pre-test peserta Penyuluhan tentang Bahaya dan Cara Penggunaan Pestisida yang Baik dan Benar

\begin{tabular}{|l|l|}
\hline Peserta & Skor \\
\hline 1 & 8 \\
\hline 2 & 7 \\
\hline 3 & 5 \\
\hline 4 & 6 \\
\hline 5 & 8 \\
\hline 6 & 7 \\
\hline 7 & 4 \\
\hline 8 & 3 \\
\hline 9 & 4 \\
\hline 10 & 6 \\
\hline 11 & 7 \\
\hline 12 & 3 \\
\hline 13 & 2 \\
\hline 14 & 8 \\
\hline 15 & 4 \\
\hline Rata-rata & 5,5 \\
\hline
\end{tabular}

Setelah dilakukan pre-test, kemudian disampaikan materi terkait dengan pestisida, bahaya pestisida dan pemakaian pestisida yang baik dan benar. Materi diberikan dalam bentuk workshop, karena selain dijelaskan menggunakan powerpointslide, materi juga diperjelas dengan video dan simulasi langsung. Seperti digambarkan pada foto berikut ini.

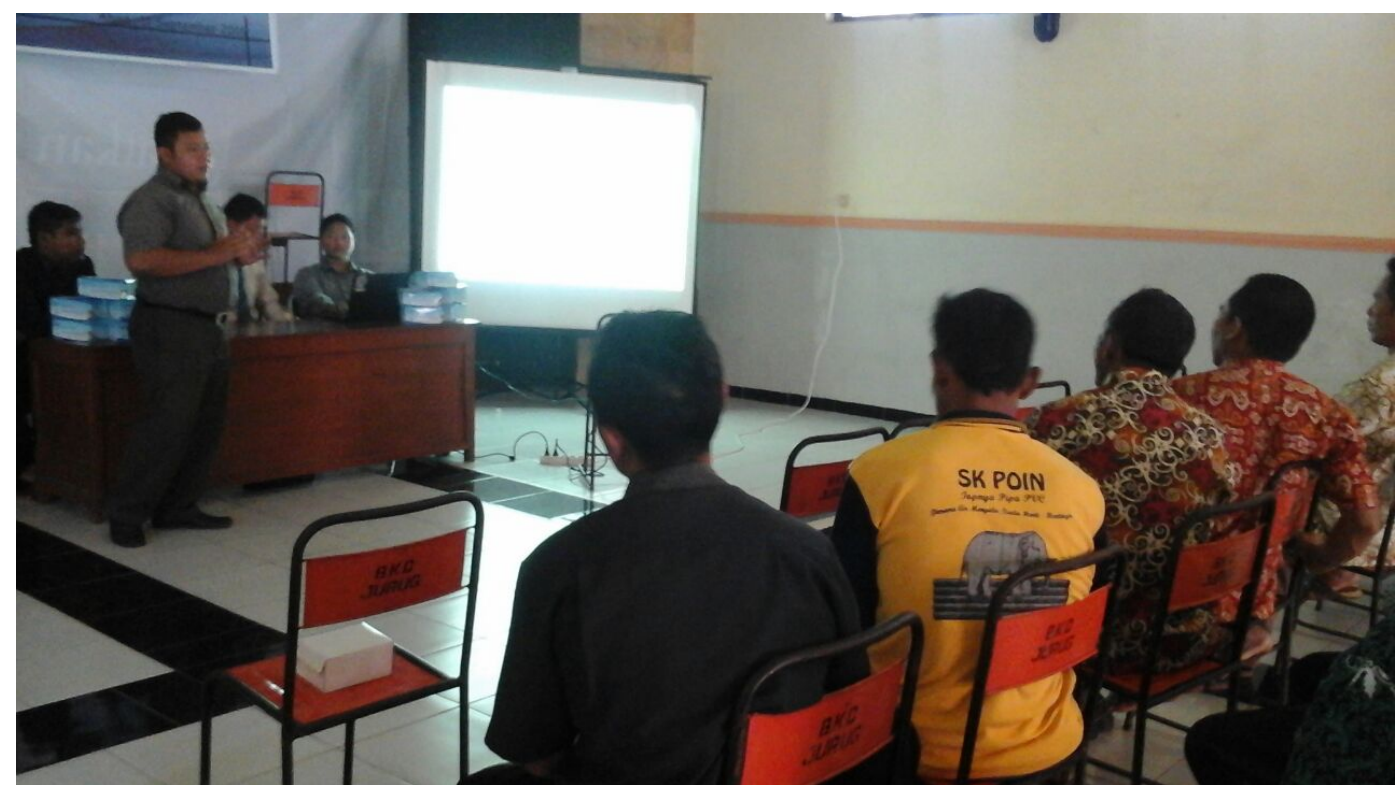

Gambar 1. Situasi penyuluhan tentang bahaya dan penggunaan pestisida yang baik dan aman

Kegiatan penyuluhan dan workshop diakhiri dengan post-test untuk menguji pemahaman peserta terhadap materi yang diberikan. Hasilnya cukup memuaskan karena terdapat peningkatan pengetahuan peserta, dibuktikan dengan meningkatnya skor rata-rata peserta sebesar $50 \%$.Rekapitulasi nilai post-test peserta ditunjukkan pada tabel dibawah ini. 
Tabel 2. Rekapitulasi nilai pos-test peserta Penyuluhan tentang Bahaya dan Cara Penggunaan Pestisida yang Baik dan Benar

\begin{tabular}{|l|l|}
\hline Peserta & Skor \\
\hline 1 & 10 \\
\hline 2 & 9 \\
\hline 3 & 7 \\
\hline 4 & 8 \\
\hline 5 & 9 \\
\hline 6 & 8 \\
\hline 7 & 8 \\
\hline 8 & 6 \\
\hline 9 & 8 \\
\hline 10 & 8 \\
\hline 11 & 8 \\
\hline 12 & 7 \\
\hline 13 & 7 \\
\hline 14 & 9 \\
\hline 15 & 8 \\
\hline Rata-rata & 8 \\
\hline
\end{tabular}

\section{Rencana Tahapan Berikutnya}

Berdasarkan rangkaian kegiatan penyuluhan yang telah dilaksanakan, diperoleh kesimpulan bahwa Petani di Desa Jurug memerlukan pendekatan dan program kesehatan terkait kegiatan pertanian.Salah satunya yaitu dengan membentuk Pos Upaya Kesehatan Kerja (UKK) pada kelompok tani.

UKK adalah Upaya Kesehatan Bersumberdaya Masyarakat (UKBM) yang memberikan pelayanan kesehatan dasar (primary health care) bagi masyarakat pekerja terutama sektor informal.Pos UKK dibentuk untuk mewadahi serangkaian kegiatan pemeliharaan kesehatan kerja yang terencana, teratur, dan berkesinambungan yang diselenggarakan sendiri oleh masyarakat pekerja.

Berikut ini adalah mind map pembentukan Pos UKK:

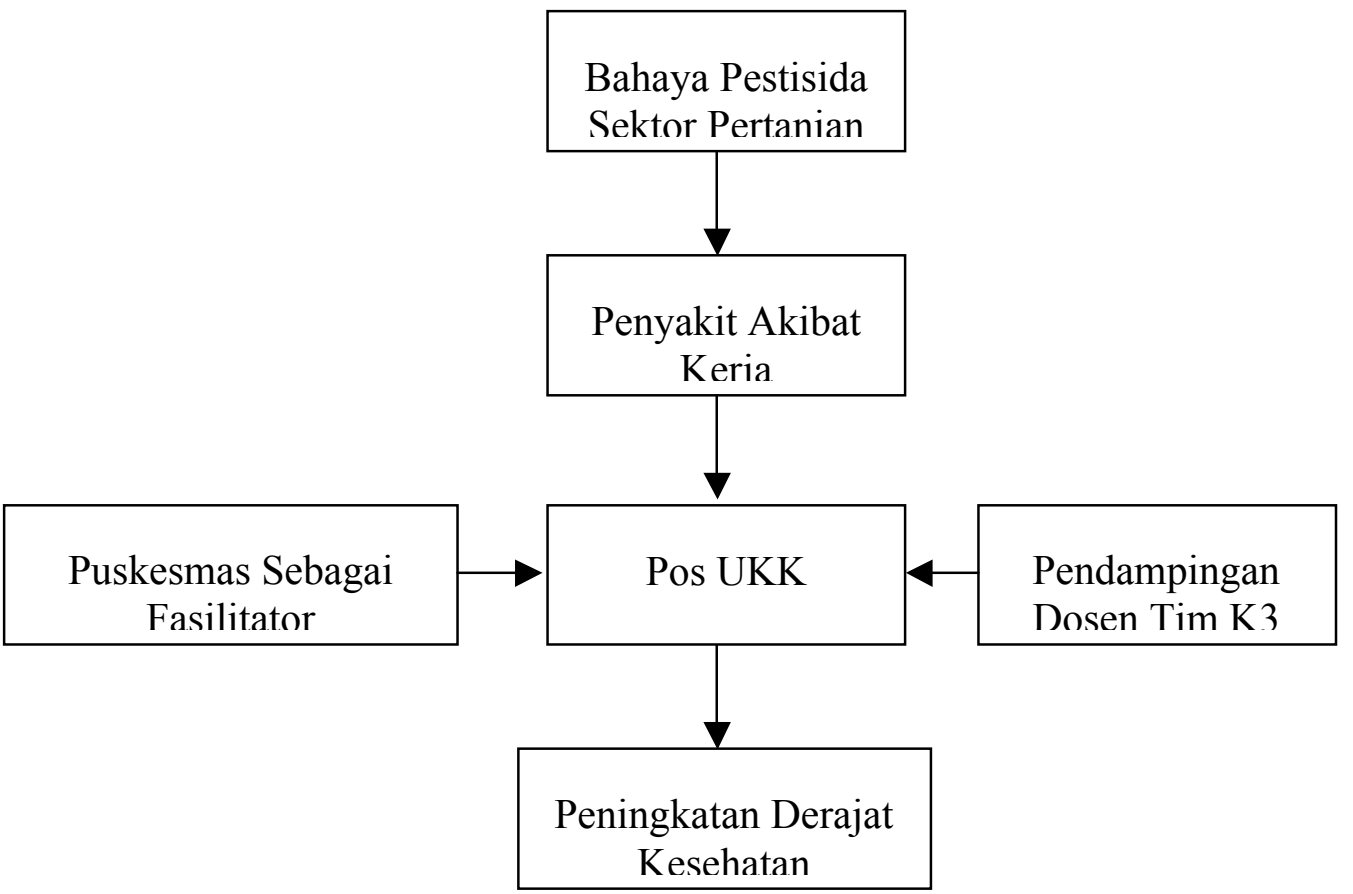

Gambar 2. Mind Map Pembentukan Pos UKK 
Pelayanan kesehatan yang diberikan meliputi peningkatan kesehatan, pencegahan penyakit dan pengobatan sederhana bagi masyarakat pekerja yang berisiko terpajan oleh pekerjaan dan lingkungan kerjanya sehingga mereka mampu menolong dirinya sendiri. Adapun syarat pembentukan pos UKK adalah terdapat tenaga kerja minimal 10 sampai dengan 50 orang dan diutamakan dari jenis pekerjaan yang sama.

Adapun peran dan fungsi Pos UKK di adalah:

1. Melakukan identifikasi masalah kesehatan di lingkungan pekerja dan sumber daya pekerja.

2. Menyusun rencana pemecahan masalah kesehatan di lingkungan kerja.

3. Melaksanakan kegiatan kesehatan di lingkungan kerja melalui promosi kesehatan kerja.

4. Menjalin kemitraan dengan berbagai pihak dalam upaya kesehatan di lingkungan kerja.

5. Melakukan pelayanan kesehatan kerja dasar.

6. Melaksanakan kewaspadaan dini terhadap berbagai risiko dan maslaah kesehatan kerja.

7. Melaksanakan rujukan ke Puskesmas.

8. Pencatatan dan Pelaporan.

Persyaratan pembentukan Pos UKK adalah sebagai berikut:

1. Ada kelompok pekerja yang membutuhkan pelayanan kesehatan kerja

2. Ada keinginan masyarakat pekerja membentuk Pos UKK

3. Ada kesediaan masyarakat menjadi kader Pos UKK

4. Ada tempat yang memadai disertai papan nama Pos UKK

5. Tersedianya peralatan P3K

6. Tersedianya APD sesuai jenis pekerjaannya

7. Alat ukur berat badan dan tinggi badan

8. Meja, kursi, tempat tidur dan lemari obat

9. Adanya buku pencatatan dan pelaporan

10. Adanya buku panduan dan media penyuluhan

11. Alat tulis

Pesyaratan nomor 1 sampai dengan 6 mutlak dipenuhisebelum dibentuk Pos UKK dan persyaratan yang lain dapat dilengkapi secara bertahap sesuai kemampuan masyarakat pekerja.

Kader Pos UKK memiliki peran yang sangat penting dalam operasionalisasi Pos UKK, dalam pengabdian ini akan melatih 2 (dua) orang kader dari masyarakat petani, dengan materi sesuai dengan tugas yang akan dikerjakan yaitu:

1. Membuat perencanaan UKK

2. Melaksanakan penyuluhan tentang K3

3. Melaksanakan P3K

4. Merujuk penderita ke Puskesmas/sarana kesehatan terdekat

5. Mengelola APD

6. Pembinaan lingkungan kerja dan cara kerja yang baik dan benar

7. Melaksanakan pencatatan dan pelaporan

Syarat orang yang dapat menjadi kader Pos UKK adalah:

1. Dipilih dari dan oleh masyarakat pekerja setempat

2. Dapat membaca dan menulis huruf latin

3. Tinggal di lingkungan tempat kerja

4. Mau dan mampu bekerja sukarela

5. Cukup waktu bekerja untuk masyarakat

6. Sudah dilatih dan paham prinsip-prinsip kesehatan kerja

Manfaat Pos UKK adalah sebagai berikut:

1. Bagi Masyarakat Pekerja

a. Permasalahan kesehatan kerja dapat dideteksi secara dini.

b. Masyarakat dapat memperoleh pelayanan kesehatan kerja yang dapat dijangkau.

2. Bagi Kader Kesehatan

a. Kader mendapatkan informasi lebih awal tentang kesehatan kerja.

b. Kader mendapatkan kebanggan.

3. Bagi Puskesmas

a. Memperluas jangkauan pelayanan Puskesmas.

b. Dapat mengoptimalkan fungsi Puskesmas utamanya pemberdayaan masyarakat.

Dengan adanya Pos UKK, selain diperuntukkan untuk Petani di Desa Demangan sendiri juga dapat dimanfaatkan oleh setiap pekerja yang menjadi anggota kelompoknya, setiap pekerja yang sehat maupun yang sakit atau yang mendapat kecelakaan kerja, serta semua anggota keluarga pekerja dan masyarakat umum yang memerlukan pelayanan kesehatan kerja dasar atau P3K. 
Jenis pelayanan kesehatan yang ada di Pos UKK Demangan nantinya terdiri dari promotif, preventif, dan kuratif. Promotif dapat berupa Perilaku Hidup Bersih dan Sehat, penyuluhan kesehatan kerja, konsultasi kesehatan kerja sederhana (gizi, berhenti merokok, APD, dan sebagainya), sarasehan untuk melakukan perubahan menuju norma sehat dalam bekerja, serta pencatatan dan pelaporan. Pelayanan preventif dapat berupa mendata jenis pekerjaan untuk mengetahui risiko yang timbul, pengenalan risiko bahaya di tempat kerja, penyediaan contoh dan kepatuhan penggunaan APD, mendorong upaya perbaikan lingkungan kerja, membantu pelaksanaan pemeriksaan awal dan berkala yang dilakukan oleh tenaga kesehatan. Pelayanan kuratif dapat berupa P3K serta pencatatan dan pelaporan.Khusus pada pekerja wanita juga dapat dikaitkan dengan kesehatan reproduksi.

Untuk keberlangsungan Pos UKK maka perlu ada anggaran atau dana, adapun dana dapat diperoleh dari dana sehat pekerja (iuran pekerja), iuran pengguna jasa Pos UKK, sumbangan yang bersifat tidak mengatur (donatur), dana stimulan dari pemerintah, dan sebagainya.

Tabel5. Tingkat Perkembangan Pos UKK

\begin{tabular}{|c|c|c|c|c|}
\hline INDIKATOR & PRATAMA & MADYA & PURNAMA & MANDIRI \\
\hline 1. P3K Kit & 1 kit $>5$ orang & $\begin{array}{l}1 \text { kit }=30-50 \\
\text { orang }\end{array}$ & $\begin{array}{l}1 \text { kit }=10-20 \\
\text { orang }\end{array}$ & $\begin{array}{l}1 \text { kit }=<10 \\
\text { orang }\end{array}$ \\
\hline 2. Jenis Obat & $<5$ jenis & $5-10$ jenis & $>10$ jenis & \\
\hline 3. Ergonomi & $<5$ jenis & $5-10$ jenis & $>10$ jenis & \\
\hline $\begin{array}{ll}\text { 4. } & \text { Sarasehan } \\
& \text { Intervensi } \\
\end{array}$ & $2 \mathrm{kali} / \mathrm{tahun}$ & $2-3 \mathrm{kali} /$ tahun & $>4$ kali/tahun & \\
\hline $\begin{array}{ll}\text { 5. Penggunaan } \\
\text { APD } \\
\end{array}$ & $<30 \%$ & $30-60 \%$ & $>60 \%$ & \\
\hline
\end{tabular}

\section{SIMPULAN}

1. Rangkaian kegiatan pengabdian ini telah sesuai target dan luaran yang direncanakan.

2. Melalui penyebaran kuesioner pretest diperoleh data bahwa sebagian besar petani belum memahami cara menggunakan pestisida yang baik dan benar serta upaya preventif dan protektif yang dilakukan.

3. Efektivitas kegiatan penyuluhan tentang penggunaan pestisida yang baik benar terlihat dalam kuesioner postest, bahwa terdapat peningkatan sebesar $50 \%$

Saran

1. Sebaiknya melakukan pembentukan Pos UKK pada industri informal untuk memenuhi pelayanan kesehatan kerja dasar.

2. Sebaiknya Pemerintah Kabupaten Ponorogo melakukan pemetaan industri informal terkait kesehatan kerja.

\section{DAFTAR PUSTAKA}

Ama, I. I., Okeme, S., and Chia, J. I. 2015.Constraints faced by Farmers in receiving Primary Healthcare Service in the North-Eastern Zone of Benue State, Nigeria. Journal of Agricultural Economics, Environment and Social Sciences 1 (1):151-154 September 2015.

Badan Pusat Statistik Kabupaten Ponorogo. 2015. Katalog Statistik daerah Kabupaten Ponorogo 2015. Badan Pusat Statistik Kabupaten Ponorogo. Ponorogo.

Costa, .G. 2008.Toxic Effects of Pesticides. Mac Millan Publishing Company. New York: 883-930.

Departemen Kesehatan RI. 2006. Pos Upaya Kesehatan Kerja. Perpustakaan Depkes RI.

Kementerian Kesehatan RI. 2010. Penuntun Hidup Sehat. Jakarta: Unicef Indonesia.

Kementerian Kesehatan RI. 2011. Pedoman Penyelenggaraan Upaya Kesehatan kerja (UKK) untuk Kader Pos UKK. Perpustakaan Depkes RI.

Kementerian Kesehatan RI. 2011. Promosi Kesehatan Di Daerah Bermasalah Kesehatan. Depkes RI.

Ming Ye, Jeremy Beach, Jonathan W. Martin, Ambikaipakan Senthilselvan. 2013. Occupational Pesticide Exposures and Respiratory Health. International Journal of Environmental Research and Public Health10, 6442-6471.

Nesheim, O. N., Fishel, F. M., \& Mossler, \&. M. (2014).Toxicity of Pesticides .IFAS Extension.

Permenakertrans RI Nomor 1758 Tahun 2003 tentang Standar Pelayanan Kesehatan Kerja Dasar.

Ramdan IM. 2012. Memperbaiki Kondisi Kesehatan Dan Keselamatan Kerja Sektor Informal Melalui Program Corporate Social Responsibility Perusahaan. Jurnal Manajemen Pelayanan Kesehatan. Volume 15 No. 1 : 2 - 6, 01 Maret 2012.

Weiss B, Amler S, Amler R. W. 2004. Pesticides.Pediatrics. 113: 1030-1036.

WHO. 2010. Exposure To Highly Hazardhous Pestiside: A Major Public Health Concern. 